representatives, armed with correct and relevant information was identified as vital. Some of the information required to address the noted challenges is already well documented, but needs to be transferred to the relevant farmer networks.

\section{ACKNOWLEDGEMENTS}

Many thanks to all the farmers and agribusiness people who gave their time freely to help with the coinnovation approach to designing new legume forage systems for hill country farming. This research was funded by the Pastoral 21 programme, a collaborative venture between DairyNZ, Fonterra, Dairy Companie Association of New Zealand, Beef + Lamb New Zealand and the Ministry of Business, Innovation and Employment.

\section{REFERENCES}

Fennessey, P.F.; Glennie, S.F.; McCorkindale, A.B 2016. Innovations behind the farm gate that will influence performance of hill farming. Grassland Research and Practice Series 16: 15-20.

Hounkonnou, D.; Kossou, D.; Kuyper, T.W.; Leeuwis, C.; Nederlof, E.S.; Röling, N.; Sakyi-Dawson, O.; Traoréj, M.; van Huis, A. 2012. An innovation systems approach to institutional change: smallholder development in West Africa. Agricultural System 108: 74-83.

Klerkx, L.; Nettle, R. 2013. Achievements and challenges of innovation co-production support initiatives in the Australian and Dutch dairy sectors: A comparative study. Food Policy 40: 74-89.

Klerkx, L.; van Mierlo, B.; Leeuwis, C. 2012. Evolution of systems approaches to agricultural innovation: concepts, analysis and interventions. pp. 457-483. In: Farming systems research into the 21st century: the new dynamic. Eds. Darnhofer, I.; Gibbon, D.; Dedieu, B. Springer, Netherlands.

Lambert, M.G.; Litherland, A.J. 2000. A practitioner's guide to pasture quality. Proceedings of the New Zealand Grassland Association 62: 111-115.

Mackay, A.D.; Costall, D.A. 2016. Long-term changes in soil fertility in hill country. Grassland Research and Practice Series 16: 157-162.

Rijswijk, K.; Small, B.; Rhodes, H.; Turner, J.; Peoples, S.; Horita, A.; Beechener, S. 2015. Heifer rearing and Canterbury nutrient me S. 2015. Heifer rearing project progress report. AgResearch, Ruakura.

Stevens, D.R.; Thompson, B.R; Carruthers, A.; Wall A.J.; Casey, M.J.; Phiskie, R.; Young, R.; Moot, D.J. 2012. Understanding the role of spring grazing of lucerne in the Central Otago environment. Proceedings of the New Zealand Grassland Association 74: 69-75.

Turner, J.; Stevens, D.; Rijswijk, K. 2014. Revitalising the role of rural professionals in primary sector innovation Primary Industry Managenert 24.

\title{
Implications of increased use of brought-in feeds on potential environmental effects of dairy farms in Waikato
}

S.F. LEDGARD ${ }^{1}$, N.L. BARTLETT ${ }^{1}$, P.J. VAN BOHEEMEN ${ }^{2}$, B.R. WILTON S.B. ALLEN ${ }^{2}$ and D.P. MUGGERIDGE

I AgResearch Ruakura, Private Bag 3123, Hamilton 3240, New Zealand ${ }^{2}$ The Tatua Co-operative Dairy Company Limited, Private Bag 800, Morrinsville 3340, New Zealand stewart.ledgard@agresearch.co.nz

\section{Abstract}

The effects of increased use of brought-in feeds were evaluated across 25 dairy farms in central Waikato. Farms were classified into low, medium and high feedinput categories based on $<500,500-1200$ and $>1200$ $\mathrm{kg} \mathrm{DM} / \mathrm{cow}$, covering a range typical of that in the main dairying regions of New Zealand. Average milksolids (MS)/ha was 1087 and $1900 \mathrm{~kg}$ in the low and high feed-input categories, but total land-use/tonne MS was the same when all off-farm land was accounted for. Average estimated on-farm nitrogen $(\mathrm{N})$ leaching increased from 26 to $30 \mathrm{~kg} \mathrm{~N} / \mathrm{ha} /$ year between the low and high feed-input categories, but off-farm leaching sources were equivalent to an increase of 20 and $84 \%$, respectively. Greenhouse gas emissions/on-farm hectare were $61 \%$ higher on high feed-input farms, but the carbon footprint and $\mathrm{N}$ leaching per tonne MS were similar across feed-inpt categoies. High feed-ine finilar acoss feed-input cact farms used feed-pads and increased effuent area (66 versus $21 \%$ of farm) to increase nutrient efficiency.
Mitigation analyses indicated that $\mathrm{N}$ leaching could be decreased by optimising effluent area, reducing $\mathrm{N}$ fertiliser rate and utilising low-N feeds.

Keywords: nitrogen leaching, whole farm system, greenhouse gases, land use

\section{Introduction}

Dairy farming in New Zealand has intensified in recent decades, with increased milk production per hectare associated with the use of nitrogen $(\mathrm{N})$ fertiliser, irrigation and increased use of brought-in feeds. For example, the average use of dry matter (DM) in brought-in feed on NZ dairy farms was $970 \mathrm{~kg} \mathrm{DM} /$ ha in 2004/2005 and $2550 \mathrm{~kg}$ DM/ha in 2014/2015 (source: ProfitWatch and DairyBase from DairyNZ).

The increased feed intake will be associated with increased nutrient intake and excretion by animals, which potentially could lead to greater losses of $\mathrm{N}$ and phosphorus $(\mathrm{P})$ to waterways. However, various management practices that affect nutrient losses, such as farm dairy effluent (FDE) management, have improved over time (e.g. PCE 2012). Farmlet research trials in Waikato have shown large increases in $\mathrm{N}$ losses with ncreased use of $\mathrm{N}$ fertiliser, relatively small changes on armlets (milking platform only) with brought-in maize silage and large potential reduction in $\mathrm{N}$ leaching with farm management and mitigations (e.g. Ledgard et al. 2006; Shepherd et al. 2017).

The aim of this study was to evaluate productivity, nutrient losses and wider environmental indicators at on-farm and whole system levels for 25 case study dairy farms in central Waikato with varying levels of use of brought-in feeds.

\section{Methods}

Twenty-five case study dairy farms from the Tatuanu area of central Waikato were selected and classified into low, medium and high feed-input levels based on brought-in feed of $<500,500-1200$ and $>1200 \mathrm{~kg}$ $\mathrm{DM} /$ cow/year. Farm numbers in each category were 6, 11 and 8, respectively. Farm records were collected for 2014/2015 and cross-checked with farmers. Thus, it uses real farm data but the wider representativeness for New Zealand in relation to level of brought-in feeds is uncertain.

Data from farms were modelled using the OVERSEER ${ }^{\circledR}$ nutrient budget model version 6.2.3 (hereafter called OVERSEER; Wheeler et al. 2003) to estimate $\mathrm{N}$ and $\mathrm{P}$ losses, and a life cycle assessment (LCA) model that complied with International Dairy Federation (IDF 2015) guidelines to estimate total greenhouse gas (GHG) emissions. The LCA accounted for all emissions from production, transportation and use of inputs from production, transportation and use of inputs including fertilisers and feeds. Modelling accounted for the dairy farm (milking platform), as well as land use for rearing replacements off-farm (based on the MP for the brought-in feed. For the latter, average published data on crop yields and inputs (e. Ledgard \& Falconer 2015) were used with assiated N leaching calcula for crop systems using OVERSEER or from published data (Schmidt 2007). Excretion of $\mathrm{N}$ by animals wa calculated in OVERSEER from the difference between $\mathrm{N}$ intake and $\mathrm{N}$ output in products. The FDE componen of this calculated in OVERSEER was based on the relative time cows spent in the farm dairy, yards and feed-pad areas. The remaining excreta-N was deposited 
on land and the proportion of this in urine and dung was calculated based on the diet $\mathrm{N}$ concentration using the equation in the New Zealand GHG Inventory.

The high feed-input farms were assessed for effects of some single mitigation practices on $\mathrm{N}$ leaching. The mitigations were based on: (i) Increasing the FDE area on the farm to reduce $\mathrm{N}$ input to below $150 \mathrm{~kg} \mathrm{~N} / \mathrm{ha}$ year and $\mathrm{K}$ input to $\leq 75 \mathrm{~kg} \mathrm{~K} / \mathrm{ha} / \mathrm{year}$, (ii) Reducing farm $\mathrm{N}$ fertiliser (non-FDE and FDE blocks) to $\leq 150$ $\mathrm{kg} N$ ha/year and replacing reduced pasture growh (assuming $10 \mathrm{~kg}$ DM/kg N response) with brough-in maize silage, or (iii) Replacing PKE with maize silage (to reduce $\mathrm{N}$ content of brought-in feed)

\section{Results}

The average milksolids (MS) production per on-farm hectare increased by $75 \%$ from the low to high feedinput categories, which was associated with an average eight-fold increase in brought-in feed (Table 1). The average MS production per cow increased from 365 to $469 \mathrm{~kg} / \mathrm{cow}$ between the low and high feed-input categories.

Pasture intake, estimated from total feed requiremen less brought-in feed adjusted for wastage (DairyNZ 2012), was similar across all feed-input categories. For each tonne (t) of MS production, the land area require

for off-farm grazing of replacements was lower for low feed-input farms due to more replacements kept on farm. Land for production of brought-in feeds was over ix-fold higher per tonne MS on high feed-input farms. The net effect was similar total land area required per t MS across all feed-input categories. There was little difference between categories in the average rate of $\mathrm{P}$ or $\mathrm{N}$ fertiliser used (Tables 1,2), although there was wide variation within all categories. There was a large increase in $\mathrm{P}$ inpt from brought in feeds a large feedinet $P$, feed-input farms. Average P runoff was similar across categories, while P surplus was lowest on low feedinput farms.

The $\mathrm{N}$ budget for the milking platform showed increased inputs of feed-N, similar fertiliser $\mathrm{N}$ use and lower calculated inputs from clover $\mathrm{N}_{2}$ fixation with increased use of brought-in feeds (Table 2). Similarly, there was increased $\mathrm{N}$ output in milk and meat by $69 \%$ and in gacous $\mathrm{N}$ losses from denitification and volatilisatio by $41 \%$ from low to high feed-input, spectively

There was a relatively small increase in calculated average $\mathrm{N}$ leaching from the low to high feed-input farms. In practice, there was some variation in soils across farms, with most being on poor-draining gley soil and some free-draining allophanic soil in all

Summary of some key farm attributes, land use and estimates of P flows from the dairy farm (milking plattorm only) for brought-in feed. Values are averages, with ranges in brackets.

\begin{tabular}{lccc}
\hline & $\begin{array}{c}\text { Low } \\
\text { (<500 kg DM/cow) }\end{array}$ & $\begin{array}{c}\text { Medium } \\
\text { (500-1200 kg DM/cow) }\end{array}$ & $\begin{array}{c}\text { High } \\
(\mathbf{1 2 0 0 - 3 2 0 0 ~ k g ~ D M / c o w ) ~}\end{array}$ \\
\hline Farm size (hectares) & $88(40-132)$ & $75(49-90)$ & $103(70-157)$ \\
Cows/ha & $2.9(2.5-3.2)$ & $3.3(3.0-3.8)$ & $4.1(3.0-6.0)$ \\
MS (kg/ha) & $1087(893-1320)$ & $1414(1284-1640)$ & $1900(1459-2690)$ \\
MS (kg/cow) & $365(322-438)$ & $421(356-461)$ & $469(388-538)$ \\
Brought-in feed (t DM/ha) & $1.0(0-1.4)$ & $2.9(2.1-3.7)$ & $8.0(3.8-13.9)$ \\
\hline Calculated data: & & & \\
Pasture intake (t DM/ha) & $14.1(11.6-15.6)$ & $14.9(13.4-18.1)$ & $14.6(13.7-17.5)$ \\
Land use (ha/t MS): & & & \\
Milking platform & 9.4 & 7.1 & 5.5 \\
Land for replacements & 2.0 & 3.5 & 3.6 \\
Crops (for brought-in feeds) & 0.3 & 1.0 & 2.1 \\
TOTAL & $11.7(9.4-15.0)$ & $11.6(10.5-12.2)$ & $11.2(9.9-12.3)$ \\
\hline P flows: & & & $14(0-39)$ \\
P fertiliser use (kg P/ha) & $22(1-44)$ & $22(0-50)$ & $34(19-58)$ \\
P in brought-in feed (kg P/ha) & $4(1-7)$ & $14(7-22)$ & $26(+3$ to +57) \\
Farm P surplus (kg P/ha) & $12(-9$ to +35$)$ & $20(-14$ to +46) & $1.0(0.7-1.6)$ \\
Prunoff risk (kg P/ha) & $1.0(0.4-1.7)$ & $1.3(0.8-2.0)$ & \\
\hline
\end{tabular}

Sum of external Pinputs minus P output in milk and meat categories. Sensitivity analysis of the effect of changing all soils to gley or allophanic in OVERSEER showed higher calculated $\mathrm{N}$ leaching from allophanic soils, but no relative changes between feed-input categories. Values were $19.5,23.1$ and $23.3 \mathrm{~kg} \mathrm{~N} / \mathrm{ha} /$ year for gley soils from low to high feed-input, respectively. Corresponding values for allophanic soils were 29.8 , 34.7 and $35.3 \mathrm{~kg} \mathrm{~N} / \mathrm{ha} / \mathrm{year}$, respectively.

Efficiency of conversion of $\mathrm{N}$ inputs to products was similar across feed-input categories, while $\mathrm{N}$ balance (diffe losses) incesed with inceesed brough-in feed large amount of $\mathrm{N}$ is cycled on-farm via excreta. The excreta-N collected in FDE and applied to land was

Nitrogen flows ( $\mathrm{kg} \mathrm{N} / \mathrm{ha} / \mathrm{year}$ ) and $\mathrm{N}$ conversion efficiency (\%) for 25 case study dairy farms (milking plattorm only) for 2014/2015, estimated using OVERSEER. Farms are separated into low, medium and high categories based on the amount of brought-in feed. Values are averages, with ranges in brackets.

\begin{tabular}{|c|c|c|c|}
\hline & $\begin{array}{c}\text { Low } \\
(<500 \mathrm{~kg} \mathrm{DM} / \mathrm{cow})\end{array}$ & $\begin{array}{c}\text { Medium } \\
\text { (500-1200 kg DM/cow) }\end{array}$ & $\begin{array}{c}\text { High } \\
(1200-3200 \mathrm{~kg} \mathrm{DM} / \mathrm{cow})\end{array}$ \\
\hline \multicolumn{4}{|l|}{ N inputs: } \\
\hline $\mathrm{N}$ fertiliser & $110(3-215)$ & $158(67-224)$ & $126(41-195)$ \\
\hline $\mathrm{N}$ fixation + atmos. deposition & $146(106-191)$ & $121(56-171)$ & $114(35-206)$ \\
\hline Feed N & $18(4-33)$ & $64(34-99)$ & $174(89-309)$ \\
\hline \multicolumn{4}{|l|}{$\mathrm{N}$ outputs/losses: } \\
\hline Products (milk + meat) & $77(63-90)$ & $100(81-128)$ & $130(98-178)$ \\
\hline Denitrification + volatilisation & $64(50-83)$ & 79 (64-108) & $90(62-131)$ \\
\hline Leaching & $26.3(20-33)$ & $28.1(20-43)$ & $29.8(21-40)$ \\
\hline$N$ balance ( $N$ inputs-outputs) & 106 & 136 & 164 \\
\hline $\mathrm{N}$ conversion efficiency $(\%)^{1}$ & 28.8 & 29.2 & 31.2 \\
\hline \multicolumn{4}{|l|}{ Excreted $\mathrm{N}^{2}:$} \\
\hline Urine-N & 302 & 335 & 336 \\
\hline Dung-N & 123 & 144 & 168 \\
\hline $\mathrm{FDE}^{3}-\mathrm{N}$ & 24 & 37 & 67 \\
\hline
\end{tabular}

${ }^{1} \mathrm{~N}$ outputs/losses $\div$ sum of $\mathrm{N}$ inputs; ${ }^{2}$ average kg $\mathrm{N} /$ halyear across milking plattorm area. ${ }^{3} \mathrm{Farm}$ dairy effluent.

Table 3 Total annual amount of $\mathrm{N}$ leached for 2014/2015 for each farm feed-input category (low, medium or high), associated with timated using OVERSER

\begin{tabular}{lccc}
\hline & Low & Medium & High \\
& $(<500$ kg DM/cow) & $(\mathbf{5 0 0 - 1 2 0 0 ~} \mathbf{~ g g ~ D M / c o w ) ~}$ & $(\mathbf{1 2 0 0 - 3 2 0 0 ~ k g ~ D M / c o w ) ~}$ \\
\hline kg N leaching/on-farm ha equivalent: & & & \\
Milking platform & 26.3 & 28.1 & 29.8 \\
Land for growing replacements & 3.4 & 7.4 & 10.2 \\
Land for brought-in feed crops & 2.0 & 8.4 & 14.7 \\
TOTAL & 31.7 & 43.9 & 54.7 \\
\hline g N leached/kg MS: & & & 28.8 \\
TOTAL & 29.1 & 30.8 & \\
\hline
\end{tabular}




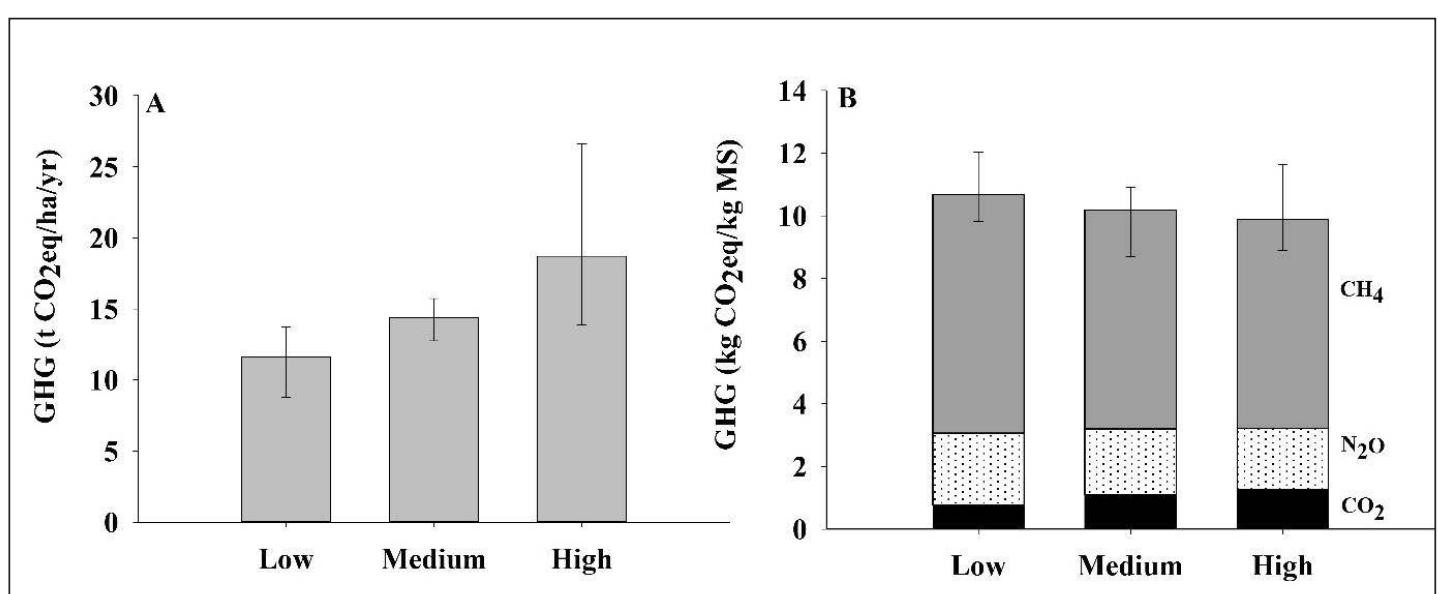

Figure 1 Total GHG emissions (A) and carbon footprint of milk (B) for each farm feed-input category (low, medium or high), expressed as carbon dioxide $\left(\mathrm{CO}_{2}\right)$ equivalents per hectare or per $\mathrm{kg} \mathrm{MS}$. Contributions from methane $\left(\mathrm{CH}_{4}\right)$, nitrous oxide $\left(\mathrm{N}_{2} \mathrm{O}\right)$ and $\mathrm{CO}_{2}$ are given. Vertical lines show the range for farms within each category.

There was a relatively large difference in the estimated values for $\mathrm{g} \mathrm{N}$ leached per $\mathrm{kg} \mathrm{DM}$ associate with the production of the different feed crops, varying between 5.0 for soybean, 3.5 for PKE and barley grain, 1.5 for maize silage and $<0.1$ for by-products such as brewers grain.

The total GHG emissions (including from all offfarm sources and production of inputs) per hectare increased with increased brought-in feed (Figure 1a) However, there was little difference in the average carbon footprint of milk (i.e. total GHG emissions $\mathrm{kg}$ MS, after allocation between milk and liveweight sold for meat) between feed-input categories (Figure $1 b)$. The high feed-input farms had relatively greater $\mathrm{CO}_{2}$ emissions from fuel use associated with crop production and use, while methane emissions $/ \mathrm{kg}$ MS were lower associated with greater $\mathrm{MS} / \mathrm{cow}$.

\section{Effects of mitigations}

Across the high feed-input farms, the mitigation option of increasing FDE area and reducing $\mathrm{N}$ fertiliser use decreased $\mathrm{N}$ leaching by an average of $16 \%$ (range $0-29 \%)$. Corresponding single mitigation analysis for reducing $\mathrm{N}$ fertiliser rate on all areas and replacing reduced feed grown with maize silage also reduced $\mathrm{N}$ leaching by an average of $17 \%$ (range $0-32 \%$ ) relative to the base farm system (with differences between farms compared to that for the FDE mitigation). Switching feed input from PKE to maize silage was estimated to decrease $\mathrm{N}$ leaching by an average of $9 \%$ (range 4-18\%)

\section{Discussion}

This study has provided an opportunity to examine the effects of increased use of brought-in feed and the association with production, resource use and potential environmental effects. There was a strong positive correlation $\left(\mathrm{R}^{2}=0.71\right)$ between $\mathrm{MS} / \mathrm{ha}$ (milking platform) and level of brought-in feed across the 25 dairy farms. This equated to an average increase of 102 $\mathrm{g}$ MS $/ \mathrm{kg} \mathrm{DM}$, which is higher than the typical average of about $60-80$ g MS $/ \mathrm{kg}$ DM (Hedley et al. 2006). This is an indirect association only and not a direct comparative trial, therefore it cannot be considered c direct efect becas the range of studied farms. However, it suggests that, on average, the farmers in this study were efficient in utilising their brought-in feeds, which was associated with a higher average MS/cow for the high feed-input group of $469 \mathrm{~kg} / \mathrm{cow}$, compared with the low feed-input group of $365 \mathrm{~kg} / \mathrm{cow}$.

\section{Land use}

While there was a large increase in MS/ha on the milking platform from low to high feed-input, the whole system analysis revealed no overall difference in efficiency of use of total land resources (i.e. total hectares used per tonne MS). The high feed-input farms had greater use of land for grazing replacements and in particular for production of the brought-in feeds. While some feeds (e.g. maize silage) produce more DM/ha soybean) are lower. Thus, the high feedinut fams have a greater relinge on land off-fan, which may be associated win geater nisk for future availability with increasing environmental constraints. It can also be associated with greater economic risk with price fluctuations in milk and feed prices, as highlighted in the Resource Efficient Dairying (RED) trial (Jensen $e t$ al. 2005). a direct effect becas than the average for pasture, others (e.g. cereal grains,

\section{Potential effects on water quality}

An important potential environmental effect of increasing farm production is on water quality and various catchments in New Zealand have plans (e.g. Lake Taupo, Rotorua lakes) or proposed plans (e.g. Waikato River, WRC 2017) that limit inputs via N leaching from land.

This study showed large variation in $\mathrm{N}$ leaching per hectare between farms, which was influenced by per hectiple site and a range of betcos (as evident by the lack of strong correlation with single input factors). One factor affecting the calculated absolute $\mathrm{N}$ leaching values was the soil characteristics and most farmland in this study was on poorer-draining gley soils, where denitrification losses are high relative to $\mathrm{N}$ leaching. However, the sensitivity analysis showed that this factor had little effect on the relative difference in $\mathrm{N}$ leaching associated with level of brought-in feeds (13-19\% higher on high than low feed-input farms on average).

The relatively small difference in farm $\mathrm{N}$ leaching with feed-input level can be explained by the determining factors for $\mathrm{N}$ leaching and management practices relating to brought-in feeds and FDE. A major determinant of $\mathrm{N}$ leaching calculated by the OVERSEER model is the amount of urine-N deposited on soil, due to the high rate of deposition of $\mathrm{N}$ that is rapidly converted to leachable $\mathrm{N}$ (Wheeler et al. 2011). In contrast, dung-N is only slowly mineralised to soluble $\mathrm{N}$ over time and leads to low losses (Selbie et al. 2015). Use of brought-in feed with a low $\mathrm{N}$ concentration relative to pasture (e.g. $2.2 \% \mathrm{~N}$ for average across feeds in high feed-input farms compared to about $3.7 \% \mathrm{~N}$ in pasture) results in greater relative utilisation by animals and proportionally more $\mathrm{N}$ excretion occurring in dung than urine (e.g. Selbie et al. 2015). Additionally, in the high feed-input farms, the greater use of feed-pad facilities resulted in much greter cuptre of exceta- $\mathrm{N}$ in FDE, which was applied across land in multiple (annulavere of $104 \mathrm{~kg} N / \mathrm{s}$ ). In (annual average of $104 \mathrm{~kg} \mathrm{~N} / \mathrm{ha}$ ). In general, FDE was managed well with the average proportion of the farm receiving FDE (range in brackets) at 21 (10-35\%), 31 $(23-42 \%)$ and $66 \%(39-100 \%)$ for low, medium and high feed-input farms, respectively.

The net effect was that the average amount of urine-N excreted on high feed-input farms was only $11 \%$ higher than that on low feed-input farms, which was of similar magnitude to the difference in farm $\mathrm{N}$ leaching. Measurements and modelling (using OVERSEER) of $\mathrm{N}$ leaching in the RED trial similarly showed a small increase in $\mathrm{N}$ leaching from the milking platform with feeding of maize silage at $5.5 \mathrm{t} \mathrm{DM} / \mathrm{ha} /$ year (Ledgard et al. 2006). However, the farm $\mathrm{N}$ balance ( $\mathrm{N}$ inputs minus $\mathrm{N}$ outputs/losses; Table 2) showed a larger average increase in soil organic-N accumulation by 58 $\mathrm{kg} \mathrm{N} / \mathrm{ha} / \mathrm{year}$ in high feed-input farms than in low feedinput farms and in the long-term this will represent a greater risk for soil-related $\mathrm{N}$ losses.

The previous comments refer to the milking platform and do not recognise that the whole farm system includes $\mathrm{N}$ leaching from off-farm areas (used for rearing replacement animals and growing brought-in eed crops). When these were included and equated fock

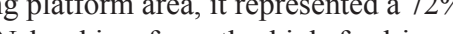
coced-input farms compared to the low feed-input farms. However, this does not relate to the potential effects from the farm system on the waterway associated with the farm, since the off-farm areas likely occur outside the local catchment. When expressed on an efficiency basis, i.e. $\mathrm{kg} \mathrm{N}$ leached per $\mathrm{kg}$ MS, there was no difference on average across the feed-input categories.

The whole-system $\mathrm{N}$ leaching (i.e. including off-farm sources) was influenced by the choice of brought-in feed, with $\mathrm{N}$ leached per tonne $\mathrm{DM}$ from the production of feeds being of the order: soybean $>$ PKE $\approx$ cereal grains $>$ maize silage $>$ by-products

Greenhouse gases

An environmental issue of global concern is climate change related to emission of GHGs (e.g. Gerber et al. 2011). This study showed an increase in GHG emissions per hectare between low and high feed-input categories of $61 \%$, which was closely related to MS/ha. Increasing GHG emissions with increased feed use and production has implications for New Zealand's commitment for meeting GHG reduction targets $(30 \%$ decrease relative to 2005 levels by 2030; MfE 2017).

However, when evaluated as GHG emissions per kg MS (i.e. the carbon footprint of milk), there was little difference between feed-input groups. This can be pribut to the greater emissions associated with feed production and use in the high feed-input group being balanced by the lower enteric methane emissions per $\mathrm{kg}$ MS associated with the higher MS/cow. The average values for the carbon footprint of milk are at the low end of the range reported for global milk production (Gerber et al. 2011).

\section{ffects of mitigation}

This study showed that average per hectare $\mathrm{N}$ losses were higher from the high feed-input farms, but that here are practical mitigation options that could bring the $\mathrm{N}$ leaching from these farms down to similar levels to that from the low-feed-input farms. Most farms in the high feed-input category had a relatively large proportion of the farm used for FDE application (66\% on average), but there were some farms that could benefit from increasing their FDE a fea (and reducing $\mathrm{N}$ 
fertiliser use accordingly), thereby reducing $\mathrm{N}$ leaching by up to $29 \%$. Nevertheless, the much greater capture and use of FDE on the high feed-input farms creates greater potential risk and increases the importance of optimal timing and efficient low-rate application of FDE (particularly on the gley soils which are sensitive to direct losses from FDE).

Nitrogen fertiliser use is a relatively cheap way of increasing pasture growth but it is inefficient in that it effect on $\mathrm{N}$ leaching per kg extra feed utilised is high et al 2011). Thus, the largest average decrease in $\mathrm{N}$ leaching calch input for $\mathrm{Nas}$. $\mathrm{N}$. $\mathrm{N} / \mathrm{ha} /$ year and replacing lost feed with maize silage. However, such analyses also need to recognise that an overall system benefit from this practice depends on efficient production and minimising $\mathrm{N}$ leaching from the maize silage crop (e.g. Williams et al. 2007).

As noted earlier, the choice of brought-in feed can also influence the on- and off-farm $\mathrm{N}$ leaching and changing from PKE to maize silage showed an average decrease in $\mathrm{N}$ leaching from the high feed-input farms of $9 \%$.

Overall, this study indicated that dairy farms with increased use of brought-in feeds were associated with increased production through increased MS/cow. They utilised practices to increase nutrient use efficiency through increased capture of excreta as FDE and preading across a greater proportion of the farm on average then the low feed-input fams. This rested in only a small

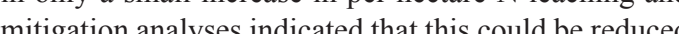
rever a N fevant farms through increased FDE area, reduce fortiser use replaced by low-N feed and switching from PKE to a low-N feed such as maize silage.

We thank the 25 dairy farmers for provision of farm data and discussions; Shelley Falconer for LCA; Bob Longhurst, Brian Devantier and Chris Smith for OVERSEER analyses. We are grateful to Bala Tikkisetty, Ian Williams, Ian Power, Paul Sharp and Aaron Traynor for their role on the project committee. We also thank MPI Sustainable Farming Fund, Ballance AgriNutrients, DairyNZ and Tatua for funding the project.

\section{REFERENCES}

DairyNZ 2012. Facts and figures for New Zealand dairy farmers. Version 2. DairyNZ. $92 \mathrm{pp}$.

Gerber, P.; Vellinga, T.; Opio. C.; Steinfeld, H. 2011. Productivity gains and greenhouse gas emission intensity in dairy systems. Livestock Science 139: 100-108.

Hedley, P.; Kolver, E.; Glassey, C.; Thorrold, B.; van Bysterveldt, A.; Roche, J.; Macdonald, K. 2006.
Achieving high performance from a range of farm systems. Proceedings of the Dairy3 Conference 4: 147-166.

F. 2015. A common carbon footprint approach for the dairy sector - The IDF guide to standard life cycle assessment methodology. Bulletin of the International Dairy Federation 479/2015. 60 pp.

Jensen, R.N.; Clark, D.A.; Macdonald, K.A. 2005. Resource efficient dairying trial. measurement criteria for farm systems over a rage of resource fer Association 67: 47-52.

Ledgard, S.; Falconer, S. 2015. Total greenhouse gas emissions from farm systems with increasing use of supplementary feeds across different regions of New Zealand. Report to MPI. RE500/2015/033. AgResearch, Hamilton. 70 pp.

Ledgard, S.F.; Luo, J.; Monaghan, R.M. 2011. Managing mineral $\mathrm{N}$ leaching in grassland systems. pp. 83-91. In: Grassland productivity and ecosystem services. Eds. Lemaire, G.; Hodgson, J.; Chabbi, A. CABI International, Wallingford, U.K.

Ledgard, S.; Sprosen, M.; Judge, A.; Lindsey, S.; Jensen, R.; Clark, D.; Luo, J. 2006. Nitrogen leaching as affected by dairy intensification and mitigation practices in the Resource Efficient Dairying (RED) trial. pp 263-268 In: Implementing sustainable nutrient management strategies in agriculture. Eds. Curie, L.D; Haty, J.A. Occasiogl Repot Eds. 19. Fetilzer and Lime Resersional Report No. 19. Fertilizer and Lime Research Centre, Mass University, Palmerston North, New Zealand.

MfE. 2017. New Zealand's 2030 climate change target. Ministry for the Environment. New Zealand Government. Available from: https://www.mfe. govt.nz/climatechange/reducing-greenhouse-gasemissions/New-Zealand\%E2\%80\%99s-post-2020climate-change-target.

PCE. 2012. Water quality in New Zealand: Understanding the science. Parliamentary Commissioner for the Environment, www.pce. parliament.nz. 93 pp.

chmidt, J.H. 2007. Life cycle assessment of rapeseed oil and palm oil. Part 3: Life cycle inventory of rapeseed oil and palm oil. Ph.D. thesis. Aalborg University, Denmark. 276 pp.

Shepherd, M.; Hedley, M.; Macdonald, K.; Chapman, D.; Monaghan, R.; Dalley, D.; Cosgrove, G.; Houlbrooke, D.; Beukes, P. 2017. A summary of key messages arising from the Pastoral 21 Research Programme In: Science and policy: nutrient management challenges for the next generation. Eds. Currie, L.D.; Hedley, M.J. http://flrc.massey. ac.nz/publications.html. Occasional Report No. 30. Fertilizer and Lime Research Centre, Massey University, Palmerston North, New Zealand. $10 \mathrm{pp}$.
Wheeler, D.M.; Cichota, R.; Snow, V.; Shepherd, M. 2011. A revised leaching model for OVERSEER $^{\circledR}$ nutrient budgets. In: Adding to the knowledge base for the nutrient manager. Eds. Currie, L.D.; Christensen, C.L. http://flrc. massey.ac.nz/publications.html. Occasional Report No. 24. Fertilizer and Lime Research Centre, Massey University, Palmerston North, New Zealand. 6 pp.

Wheeler, D.M.; Ledgard, S.F.; de Klein C.A.M.; Monaghan, R.M. Carey, P.L; McDowell, R.W; Johns, K.L. 2003. OVERSEER ${ }^{\mathbb{R}}$ nuttint Johns, K.L. 2003. OVERSEER
Proceedings of the New Zealand Grassland Association 65: 191-194.

Williams, I.D.; Ledgard, S.F.; Edmeades, G.O.; Densely, R.J. 2007. Comparative environmental impacts of intensive all-grass and maize silage-supplemented dairy farm systems: a review. Proceedings of the New Zealand Grassland Association 69: 137-143.

WRC. 2017. Summary of the proposed rules. Waikato Regional Council. https://www.waikatoregion. govt.nz/assets/PageFiles/40248/5226-The-HRWOsummary-of-rules-PR.pdf 